\title{
Outcome Predictors in Patient with Traumatic Intracerebral Hemorrhage in Hasan Sadikin General Hospital Bandung
}

\author{
Tara M Mulyawan*, M Zafrullah Arifin**, Firman P Tjahjono** \\ *Faculty of Medicine Padjadjaran University \\ ** Department of Neurosurgery Faculty of Medicine Padjadjaran University \\ Jl. Prof. Eyckman No. 38 Bandung 40161 Indonesia \\ Email : tarmud98@gmail.com
}

\begin{abstract}
Predictions about patient outcomes can help doctors make decisions. Intracerebral hemorrhage acccompanied by brain injury can increase mortality but specific studies on outcomes of patients with traumatic intracerebral hemorrhage are still rare. The purpose of this study was to determine the factors that influence the outcome of traumatic intracerebral hemorrhage patients in the RSHS period from January to December 2017. This is an observational study with cross sectional method, categorical comparative analytic. The study involved 60 traumatic intracerebral hemorrhages aged $\geq 15$ years who were hospitalized in RSHS. The data was analyzed univariately and bivariately using Chi Square statistical test, Eta correlation test and contingency coefficient. The results showed age ( $p=0.003), G C S$ scores assessed at admission ( $p<0.001)$, and the presence or absence of other brain hemorrhages $(p=$ $0.050)$ significantly affected the patient's outcome. Gender $(p=0.932)$, mechanism of injury ( $p$ $=0.739)$, and pupillary response $(p=0.056)$ did not affect the outcome significantly. In conclusion, the factors that influence the outcome of traumatic intracerebral hemorrhage patients are age, GCS score, and presence or absence of other brain hemorrhages.
\end{abstract}

Keywords: intracerebral hemorrhage, trauma, predictors, outcome 


\title{
Prediktor Luaran pada Pasien dengan Perdarahan Intraserebral Traumatik di Rumah Sakit Umum Hasan Sadikin Bandung
}

\author{
Tara M Mulyawan*, M Zafrullah Arifin**, Firman P Tjahjono** \\ *Fakultas Kedokteran Universitas Padjadjaran \\ **Departemen Bedah Saraf Fakultas Kedokteran Universitas Padjadjaran \\ Jl. Prof. Eyckman No. 38 Bandung 40161 Indonesia \\ Email : tarmud98@gmail.com
}

\begin{abstract}
Abstrak
Prediksi mengenai luaran pasien dapat membantu dokter dalam mengambil keputusan. Perdarahan intraserebral yang menyertai cedera otak dapat meningkatkan mortalitas namun penelitian spesifik terhadap luaran pasien dengan perdarahan intraserebral traumatik masih jarang dilakukan. Tujuan dari penelitian ini adalah mengetahui faktor-faktor yang memengaruhi luaran pasien perdarahan intraserebral traumatik di RSHS periode Januari sampai Desember 2017. Penelitian ini bersifat observasional dengan metode penelitian cross sectional, analitik komparatif kategorik. Penelitian ini melibatkan 60 pasien perdarahan intraserebral traumatik berusia $\geq 15$ tahun yang menjalani rawat inap di RSHS. Data dianalisis dalam bentuk univariat dan bivariat dengan menggunakan uji statistik Chi Square, uji korelasi Eta dan koefisien kontingensi. Hasil penelitian menunjukkan usia $(p=0,003)$, skor GCS yang dinilai saat masuk rumah sakit $(\mathrm{p}<0,001)$, serta ada atau tidaknya perdarahan otak lain $(\mathrm{p}=0,050)$ memengaruhi luaran pasien secara signifikan. Jenis kelamin $(\mathrm{p}=0,932)$, mekanisme cedera $(\mathrm{p}=0,739)$, dan respon pupil $(\mathrm{p}=0,056)$ tidak memengaruhi luaran secara signifikan. Sebagai simpulan, faktorfaktor yang memengaruhi luaran pasien perdarahan intraserebral traumatik adalah usia, skor GCS, dan ada tidaknya perdarahan otak lain.
\end{abstract}

Kata kunci: perdarahan intraserebral traumatik, trauma, prediktor, luaran 


\section{Research Article}

\section{Pendahuluan}

Cedera kepala adalah gangguan struktur dan fungsi otak yang diakibatkan oleh gaya mekanik dari luar tubuh. ${ }^{1,2}$ Tingkat kejadian cedera kepala di Indonesia masih tinggi. Penyebab utama cedera kepala di Indonesia adalah kecelakaan yang melibatkan kendaraan bermotor, terutama roda dua. ${ }^{2-5}$ Menurut Riset Kesehatan Dasar tahun 2018, tempat terjadinya cedera paling banyak di jalan raya, sebesar $44,7 \%$. Tujuh puluh dua koma tujuh persen cedera akibat kecelakaan lalu lintas terjadi pada pengendara sepeda motor. ${ }^{6}$

Perdarahan intraserebral adalah perdarahan yang terjadi di parenkim otak dan paling banyak disebabkan oleh cedera kepala. ${ }^{7}$ Penelitian di Inggris menunjukkan adanya peningkatan mortalitas pada cedera kepala yang disertai perdarahan intraserebral (perdarahan intraserebral traumatik) dibandingkan cedera kepala yang tidak disertai pendarahan intraserebral. ${ }^{8}$ Tingginya tingkat kejadian serta peningkatan mortalitas pada pasien cedera kepala yang disertai perdarahan intraserebral menjadikannya suatu masalah yang harus diperhatikan.

Beberapa penelitian menunjukkan bahwa faktor-faktor yang memengaruhi luaran pasien dengan cedera kepala meliputi usia, jenis kelamin, mekanisme trauma, skor Glasgow Coma Scale (GCS), respon pupil yang dinilai saat pertama kali pasien masuk ke rumah sakit, dan lesi perdarahan otak yang menyertai cedera kepala. ${ }^{5,7,8,11-14}$ Penelitian di Rotterdam menunjukkan tingginya angka mortalitas pada kelompok pasien cedera kepala usia $\geq 65$ tahun, yaitu mencapai $72 \%$, walaupun jumlah pasien usia $\geq 65$ tahun lebih sedikit dibandingkan pasien usia 15-64 tahun. ${ }^{13}$ Penelitian di Athena menunjukkan tingkat mortalitas pada pasien perempuan $(34,95 \%)$ lebih tinggi dibandingkan pasien laki-laki (24,83\%). Berdasarkan mekanisme cedera, penyebab terbanyak cedera adalah kecelakaan kendaraan bermotor dengan tingkat mortalitas paling tinggi yaitu sebesar $28,31 \%{ }^{14}$

Penelitian di China menunjukkan pasien cedera kepala dengan skor GCS yang semakin rendah dan respon pupil bilateral abnormal memiliki tingkat mortalitas yang lebih tinggi. ${ }^{5}$ Penelitian di Belanda menunjukkan pasien dengan tipe perdarahan otak multipel memiliki tingkat mortalitas 2,8 kali lebih tinggi dibandingkan pasien dengan satu tipe perdarahan spesifik. ${ }^{15}$ Perdarahan intraserebral yang menyertai cedera otak dapat meningkatkan mortalitas namun penelitian spesifik terhadap luaran pasien dengan perdarahan intraserebral traumatik masih jarang dilakukan. Penelitian lebih lanjut mengenai faktor-faktor yang memengaruhi luaran pasien cedera kepala perlu dilakukan, khususnya pada pasien dengan perdarahan intraserebral traumatik.

Tujuan penelitian ini adalah menentukan faktor-faktor yang mempengaruhi luaran pasien perdarahan intraserebral traumatik di Rumah Sakit Hasan Sadikin (RSHS) Bandung pada 


\section{Research Article}

periode Januari sampai Desember 2017. Penelitian ini diharapkan dapat memberikan data mengenai faktor-faktor yang mempengaruhi keluaran pasien dengan perdarahan intraserebral traumatik serta dapat menjadi dasar pertimbangan pengambilan keputusan dalam penanganan pasien perdarahan intraserebral traumatik. Dengan penanganan pasien yang lebih baik pada akhirnya diharapkan dapat menurunkan angka kematian.

\section{Metode}

Penelitian ini menggunakan metode cross sectional, analitik komparatif kategorik. Populasi penelitian ini adalah seluruh pasien perdarahan intraserebral traumatik yang sudah didiagnosis berdasarkan hasil $C T$ scan dan tercatat pada rekam medis di Departemen Bedah Saraf RSHS Bandung periode Januari sampai Desember 2017. Pengambilan data dilakukan menggunakan metode total sampling pada bulan April sampai Juni 2018. Penelitian ini telah disetujui oleh Komite Etik Penelitian Kesehatan Fakultas Kedokteran Universitas Padjajaran dengan surat izin penelitian No. 2749/UN6.C1/DL/2018. Data penelitian merupakan data sekunder yang berasal dari laporan jaga departemen Bedah Saraf dan rekam medis pusat RSUP dr. Hasan Sadikin Bandung. Kriteria inklusi pada penelitian ini meliputi pasien laki-laki dan perempuan berusia $\geq 15$ tahun pada awal tahun 2017 dan didiagnosis perdarahan intraserebral traumatik berdasarkan hasil $C T$ scan kepala. Kriteria ekslusi meliputi pasien dengan informasi yang tidak lengkap pada rekam medis.

Data pasien yang didapat dari laporan jaga departemen Bedah Saraf meliputi usia, jenis kelamin, mekanisme kejadian, skor GCS saat masuk rumah sakit, respon pupil, serta ada atau tidaknya perdarahan otak lain yang menyertai. Usia, jenis kelamin, mekanisme kejadian, skor GCS saat masuk rumah sakit, respon pupil, serta ada atau tidaknya perdarahan otak lain yang menyertai merupakan variabel bebas, sedangkan luaran pasien merupakan variabel terikat.

Analisis data meliputi analisis univariat dan bivariat. Hasil analisis data univariat disajikan dalam bentuk tabel karakteristik dasar pasien perdarahan intraserebral traumatik yang meliputi jumlah serta persentase. Hasil analisis data bivariat disajikan dalam bentuk tabel yang menghubungkan faktor-faktor yang memengaruhi luaran pasien dengan luaran pasien perdarahan intraserebral traumatik. Uji hipotesis pada penelitian ini dilakukan menggunakan metode Chi Square dan dinyatakan bermakna jika $\mathrm{p}<0,05$. Kekuatan hubungan antara variabel bebas dan terikat diuji menggunakan uji korelasi Eta dan koefisien kontingensi. Analisis dan penyajian data dilakukan dengan bantuan perangkat lunak Microsoft Excel dan Statistical Program for Social Science (SPSS). 


\section{Research Article}

Hasil

Tabel 1 menunjukkan karakteristik dasar pasien perdarahan intraserebral traumatik di RSHS periode Januari - Desember 2017. Dari penelitian ini terkumpul 60 data yang memenuhi kriteria. Rata-rata pasien perdarahan intraserebral traumatik di RSHS berusia 15 - 64 tahun $(86,7 \%)$ dengan sebagian besar pasien berjenis kelamin laki-laki $(76,7 \%)$. Perdarahan intraserebral traumatik paling banyak disebabkan oleh kecelakaan kendaraan bermotor $(73,3 \%)$. Skor GCS pasien perdarahan intraserebral traumatik saat masuk rumah sakit paling banyak antara 9-12 (53,0\%). Respon pupil pasien saat masuk rumah sakit mayoritas bilateral normal $(85,0 \%)$. Sebagian besar pasien perdarahan intraserebral traumatik disertai dengan perdarahan otak lain, seperti perdarahan subdural, epidural, dan subaraknoid (73,3\%). Luaran pasien dengan perdarahan intraserebral traumatik di RSHS sebagian besar hidup (85,0\%).

Tabel 1 Karakteristik Dasar Pasien Perdarahan Intraserebral Traumatik Di RSHS

\begin{tabular}{|c|c|c|}
\hline Karakteristik & Jumlah (n) & Persentase $(\%)$ \\
\hline \multicolumn{3}{|l|}{ Usia } \\
\hline $15-64$ tahun & 52 & 86,7 \\
\hline$\geq 65$ tahun & 8 & 13,3 \\
\hline \multicolumn{3}{|l|}{ Jenis kelamin } \\
\hline Laki-laki & 46 & 76,7 \\
\hline Perempuan & 14 & 23,3 \\
\hline \multicolumn{3}{|l|}{ Mekanisme } \\
\hline Kecelakaan kendaraan bermotor & 44 & 73,3 \\
\hline Jatuh & 13 & 21,7 \\
\hline Kecelakaan di tempat kerja & 1 & 1,7 \\
\hline Lain-lain & 2 & 3,3 \\
\hline \multicolumn{3}{|l|}{ Skor GCS } \\
\hline $13-15$ & 21 & 35,0 \\
\hline $9-12$ & 32 & 53,0 \\
\hline $3-8$ & 7 & 11,7 \\
\hline \multicolumn{3}{|l|}{ Respon pupil } \\
\hline Bilateral normal & 51 & 85,0 \\
\hline Unilateral abnormal & 8 & 13,3 \\
\hline Bilateral abnormal & 1 & 1,7 \\
\hline \multicolumn{3}{|l|}{ Lesi perdarahan otak lain } \\
\hline Tidak ada & 16 & 26,7 \\
\hline Ada & 44 & 73,3 \\
\hline \multicolumn{3}{|l|}{ Luaran } \\
\hline Hidup & 51 & 85,0 \\
\hline Mati & 9 & 15,0 \\
\hline
\end{tabular}


Tabel 2 Hubungan Faktor-Faktor terhadap Luaran Pasien Perdarahan Intraserebral Traumatik

\begin{tabular}{|c|c|c|c|c|c|c|}
\hline \multirow{2}{*}{\multicolumn{2}{|c|}{ Karakteristik Pasien }} & \multicolumn{2}{|c|}{ Luaran } & \multirow[b]{2}{*}{ Total } & \multirow[b]{2}{*}{ Nilai P } & \multirow{2}{*}{$\begin{array}{c}\text { Kekuatan } \\
\text { Korelasi (r) }\end{array}$} \\
\hline & & Hidup & Mati & & & \\
\hline Usia & $\begin{array}{l}15-64 \\
\geq 65 \\
\text { Total }\end{array}$ & $\begin{array}{c}47 \\
(90,4 \%) \\
4 \\
(50,0 \%) \\
51 \\
(85,0 \%)\end{array}$ & $\begin{array}{c}5 \\
(9,6 \%) \\
4 \\
(50,0 \%) \\
9 \\
(15,0 \%)\end{array}$ & $\begin{array}{c}52 \\
(100 \%) \\
8 \\
(100 \%) \\
60 \\
(100 \%)\end{array}$ & 0,003 & 0,384 \\
\hline Jenis Kelamin & $\begin{array}{l}\text { Laki-laki } \\
\text { Perempuan } \\
\text { Total }\end{array}$ & $\begin{array}{c}39 \\
(84,8 \%) \\
12 \\
(85,7 \%) \\
51 \\
(85,0 \%)\end{array}$ & $\begin{array}{c}7 \\
(15,2 \%) \\
2 \\
(14,3 \%) \\
9 \\
(15,0 \%)\end{array}$ & $\begin{array}{c}46 \\
(100 \%) \\
14 \\
(100 \%) \\
60 \\
(100 \%)\end{array}$ & 0.932 & 0.011 \\
\hline $\begin{array}{l}\text { Mekanisme } \\
\text { Cedera }\end{array}$ & $\begin{array}{l}\text { Kecelakaan } \\
\text { kendaraan bermotor } \\
\text { Jatuh } \\
\text { Kecelakaan di } \\
\text { tempat kerja } \\
\text { Lain-lain } \\
\text { Total }\end{array}$ & $\begin{array}{c}38 \\
(86,4 \%) \\
10 \\
(76,9 \%) \\
1 \\
(100 \%) \\
2 \\
(100 \%) \\
51 \\
(85,0 \%)\end{array}$ & $\begin{array}{c}6 \\
(13.6 \%) \\
3 \\
(23,1 \%) \\
0 \\
(0 \%) \\
0 \\
(0 \%) \\
9 \\
(15,0 \%)\end{array}$ & $\begin{array}{c}44 \\
(100 \%) \\
13 \\
(100 \%) \\
1 \\
(100 \%) \\
2 \\
(100 \%) \\
60 \\
(100 \%)\end{array}$ & 0,739 & 0,143 \\
\hline Skor GCS & $\begin{array}{l}13-15 \\
9-12 \\
3-8 \\
\text { Total }\end{array}$ & $\begin{array}{c}21 \\
(100 \%) \\
29 \\
(90,6 \%) \\
1 \\
(14,3 \%) \\
51 \\
(85,0 \%)\end{array}$ & $\begin{array}{c}0 \\
(0 \%) \\
3 \\
(9,4 \%) \\
6 \\
(85,7 \%) \\
9 \\
(15,0 \%)\end{array}$ & $\begin{array}{c}21 \\
(100 \%) \\
32 \\
(100 \%) \\
7 \\
(100 \%) \\
60 \\
(100 \%)\end{array}$ & 0,000 & 0,730 \\
\hline Respon Pupil & $\begin{array}{l}\text { Bilateral } \\
\text { normal } \\
\text { Unilateral abnormal } \\
\text { Bilateral abnormal } \\
\text { Total }\end{array}$ & $\begin{array}{c}44 \\
(86,3 \%) \\
7 \\
(87,5 \%) \\
0 \\
(0 \%) \\
51 \\
(85.0 \%)\end{array}$ & $\begin{array}{c}7 \\
(13,7 \%) \\
1 \\
(12,5 \%) \\
1 \\
(100 \%) \\
9 \\
(15.0 \%)\end{array}$ & $\begin{array}{c}51 \\
(100 \%) \\
8 \\
(100 \%) \\
1 \\
(100 \%) \\
60 \\
(100 \%)\end{array}$ & 0,056 & 0,296 \\
\hline $\begin{array}{l}\text { Perdarahan Otak } \\
\text { Lain }\end{array}$ & $\begin{array}{l}\text { Ada } \\
\text { Total }\end{array}$ & $\begin{array}{c}16 \\
(100 \%) \\
35 \\
(79,5 \%) \\
51 \\
(85,0 \%)\end{array}$ & $\begin{array}{c}0 \\
(0 \%) \\
9 \\
(20,5 \%) \\
9 \\
(15,0 \%)\end{array}$ & $\begin{array}{c}16 \\
(100 \%) \\
44 \\
(100 \%) \\
60 \\
(100 \%)\end{array}$ & 0,050 & 0,246 \\
\hline
\end{tabular}

Keterangan :

GCS : Glasgow Coma Scale 


\section{Research Article}

Tabel 2 menunjukkan hasil uji hipotesis serta uji korelasi antara faktor dan luaran pasien perdarahan intraserebral traumatik. Hubungan usia terhadap luaran pasien dinilai melalui uji statistik korelasi menggunakan korelasi Eta. Nilai $\mathrm{p} \leq 0,05(0,003)$ menunjukkan korelasi antara kelompok usia dan luaran pasien bermakna secara statistik. Nilai korelasi sebesar 0,384 menunjukkan korelasi positif dengan kekuatan korelasi lemah.

Hubungan jenis kelamin terhadap luaran pasien dinilai melalui uji statistik korelasi menggunakan korelasi koefisien kontingensi. Nilai $p>0,05(0,932)$ menunjukkan korelasi antara jenis kelamin dan luaran pasien tidak bermakna secara statistik. Nilai korelasi sebesar 0,011 menunjukkan korelasi positif dengan kekuatan korelasi sangat lemah. Hubungan mekanisme cedera terhadap luaran pasien dinilai melalui uji statistik korelasi menggunakan korelasi koefisien kontingensi. Nilai $\mathrm{p}>0,005(0,739)$ menunjukkan korelasi antara mekanisme cedera dan luaran pasien tidak bermakna secara statistik. Nilai korelasi sebesar 0,143 menunjukkan korelasi positif dengan kekuatan korelasi sangat lemah.

Hubungan skor GCS terhadap luaran pasien dinilai melalui uji statistik korelasi menggunakan korelasi Eta. Nilai $\mathrm{p} \leq 0,05(<0,001)$ menunjukkan korelasi antara skor GCS dan luaran pasien bermakna secara statistik. Nilai korelasi sebesar 0,730 menunjukkan korelasi positif dengan kekuatan korelasi yang kuat. Hubungan respon pupil terhadap luaran pasien dinilai melalui uji statistik korelasi menggunakan korelasi koefisien kontingensi. Nilai $p>0,05$ $(0,056)$ menunjukkan korelasi antara respon pupil dan luaran pasien tidak bermakna secara statistik. Nilai korelasi sebesar 0,296 menunjukkan korelasi positif dengan kekuatan korelasi yang lemah.

Hubungan ada tidaknya perdarahan otak lain terhadap luaran pasien dinilai melalui uji statistik korelasi menggunakan korelasi koefisien kontingensi. Nilai $\mathrm{p} \leq 0,05$ menunjukkan korelasi antara ada tidaknya perdarahan otak lain dan luaran pasien bermakna secara statistik. Nilai korelasi sebesar 0,246 menunjukkan korelasi positif dengan kekuatan korelasi yang lemah.

\section{Diskusi}

Sebagian besar pasien yang mengalami perdarahan intraserebral traumatik berusia antara 15 sampai 64 tahun (86,7\%). Hal ini berkaitan dengan jumlah pengemudi kendaraan bermotor yang sebagian besar merupakan masyarakat usia produktif. Menurut data dari KORLANTAS POLRI, kecelakaan kendaraan bermotor, yang merupakan penyebab utama cedera kepala, paling rentan terjadi pada kelompok usia 15-25 tahun. Pengemudi kelompok usia ini belum menyadari risiko dari perilaku mengemudi yang tidak sesuai aturan. 


\section{Research Article}

Luaran pasien perdarahan intraserebral traumatik kelompok usia $\geq 65$ tahun lebih buruk dibandingkan dengan kelompok usia 15 - 64 tahun dengan jumlah kematian mencapai 50,0\%, walaupun jumlah pasien kelompok usia $\geq 65$ tahun lebih sedikit (13,3\%). Hasil ini sesuai dengan penelitian di Rotterdam yang menunjukkan angka mortalitas pada kelompok pasien usia $\geq 65$ tahun mencapai 75\%. ${ }^{13}$ Beberapa hal menyebabkan buruknya luaran pada pasien kelompok usia tua yaitu berkurangnya jumlah neuron di otak serta kerusakan repetitif minor pada otak yang terus bertambah seiring dengan bertambahnya usia menyebabkan penurunan kemampuan penyembuhan neuron setelah adanya trauma. ${ }^{13}$ Perlu diingat bahwa kesimpulan dari hasil penelitian ini hanya dapat diterapkan pada pasien usia 15 tahun dan lebih karena batas bawah kelompok usia subjek penelitian adalah 15 tahun.

Jenis kelamin tidak memengaruhi luaran pasien perdarahan intraserebral traumatik, walaupun jumlah pasien laki-laki lebih banyak daripada perempuan $(76,7 \%)$. Salah satu alasannya adalah jumlah pengemudi kendaraan bermotor berjenis kelamin laki-laki yang lebih banyak daripada pengemudi perempuan sehingga meningkatkan resiko laki-laki untuk mengalami kecelakaan kendaraan bermotor.

Kecelakan yang melibatkan kendaraan bermotor merupakan penyebab utama perdarahan intraserebral traumatik. ${ }^{14}$ Hasil penelitian ini menunjukkan perdarahan intraserebral traumatik paling banyak disebabkan oleh kecelakaan yang melibatkan kendaraan bermotor $(73,3 \%)$ dan jatuh $(21,7 \%)$. Kecelakaan kendaraan bermotor sebagai penyebab utama perdarahan intraserebral traumatik sesuai dengan data dari KORLANTAS POLRI yang menunjukkan jumlah kecelakan kendaraan bermotor di Indonesia mencapai 25.000 kejadian sejak Januari sampai Maret 2018, dengan jumlah korban meninggal mencapai lebih dari 5000 jiwa. Mekanisme cedera tidak memengaruhi luaran pasien.

Berdasarkan hasil penelitian ini, pencegahan perdarahan intraserebral traumatik dapat dilakukan melalui upaya peningkatan keselamatan pengguna jalan raya, termasuk pengemudi, penumpang, serta pejalan kaki. ${ }^{15,19}$ Upaya yang dapat dilakukan meliputi penetapan batas kecepatan, penggunaan helm yang memenuhi standar, pemakaian sabuk pengaman, serta edukasi kepada kelompok masyarakat yang memiliki resiko tinggi, yaitu pengguna jalan kelompok usia 15-25 tahun. Selain keselamatan di jalan raya, faktor lain yang harus diperhatikan untuk mencegah terjadinya perdarahan intraserebral traumatik adalah kesehatan dan keselamatan kerja. Salah satu upaya meningkatkan keselamatan kerja adalah dengan menyediakan Alat Perlindung Diri (APD) sesuai Peraturan Menteri Tenaga Kerja dan Transmigrasi No. Per.08/Men/VII/2010 tentang Alat Pelindung Diri. 


\section{Research Article}

Penilaian GCS merupakan sistem pengukuran kesadaran yang diperkenalkan oleh Teasdale and Jennett pada tahun 1974 dan digunakan di seluruh dunia, memiliki rentang skor 3 sampai $15 .{ }^{16}$ GCS saat masuk rumah merupakan salah satu faktor yang paling signifikan memengaruhi luaran pasien perdarahan intraserebral traumatik. ${ }^{9,14}$ Hasil penelitian menunjukkan peningkatan angka kematian yang signifikan pada kelompok pasien dengan skor GCS 3 sampai 8 saat masuk rumah sakit, mencapai 85,7\%, sesuai dengan penelitian-penelitian sebelumnya. $^{9}$

Perdarahan intraserebral traumatik yang merupakan jenis lesi supratentorial menyebabkan herniasi pada hemisfer otak sehingga menimbulkan gejala klinis seperti kontralateral hemiparesis, gangguan hemisensori kontralateral, dan afasia. ${ }^{17}$ Lesi supratentorial yang semakin parah dapat menyebabkan terjadinya herniasi pada struktur-struktur yang terletak di bawah lesi primer seperti talamus, mesensefalon (midbrain), pons, dan medula. Kerusakan pada struktur-struktur yang berfungsi untuk mengatur kesadaran dan kewaspadaan menyebabkan munculnya gejala klinis berupa penurunan kesadaran. Penurunan kesadaran pada pasien dapat dinilai dengan GCS, di mana pasien koma memiliki nilai GCS kurang dari 9. ${ }^{16}$ Kemungkinan pasien dewasa untuk sembuh total tanpa adanya gangguan neurologis yang signifikan menurun drastis setelah kerusakan mencapai tingkat mesensefalon dan mayoritas luaran pasien buruk saat kerusakan mencapai tingkat pons. ${ }^{17}$

Faktor selanjutnya yang memengaruhi luaran pasien perdarahan intraserebral traumatik adalah respon pupil yang dinilai saat pasien masuk rumah sakit. Penelitian sebelumnya menunjukkan angka kematian pasien dengan respon pupil bilateral normal lebih rendah dibandingkan dengan respon pupil unilateral abnormal dan bilateral normal. ${ }^{5,9}$ Pada penelitian ini, respon pupil pasien mayoritas bilateral normal $(85,0 \%)$ serta tidak didapatkan pengaruh respon pupil terhadap luaran pasien yang signifikan. Lesi supratentorial seperti perdarahan intraserebral traumatik dapat menyebabkan herniasi pada unkus serta saraf okulomotor. Abnormalitas respon pupil yang merupakan akibat dari kompresi saraf okulomotor merupakan tanda terjadinya herniasi transtentorial. ${ }^{16}$ Terbatasnya jumlah sampel pada penelitian ini merupakan salah satu penyebab tidak adanya pengaruh respon pupil terhadap luaran pasien yang signifikan.

Trauma kepala seringkali menyebabkan lebih dari satu jenis pendarahan (73,3\%). Hasil dari penelitian ini menunjukkan luaran pasien perdarahan intraserebral traumatik dipengaruhi dengan ada tidaknya perdarahan otak lain seperti perdarahan subdural, epidural, dan subaraknoid. Adanya pendarahan otak lain menyebabkan herniasi yang semakin parah sehingga terjadi gangguan fungsi otak serta luaran pasien yang semakin buruk. Keterbatasan dari 


\section{Research Article}

penelitian ini adalah tidak dilakukan pengamatan lebih lanjut terhadap luaran paska perdarahan intraserebral traumatik menggunakan Glasgow Outcome Scale (GOS). Penilaian GOS pertama kali dikembangkan oleh Jennet dan Bond pada tahun 1975 yang bertujuan untuk mengklasifikasikan luaran pada pasien paska cedera kepala. ${ }^{18}$ GOS terdiri dari 5 kategori yaitu good recovery, moderate deficits, severe deficits, vegetative status, dan death.

Penilaian GCS pada penelitian ini tidak memperhatikan ada tidaknya penanganan fase pra rumah sakit yang diberikan pada pasien. Padahal, penanganan pasien fase pra rumah sakit, seperti pemberian sedasi dan intubasi, dapat memengaruhi skor GCS pasien saat masuk rumah sakit. Selain itu, analisis data pada penelitian ini dilakukan secara univariat dan bivariat saja tanpa adanya analisis multivariat sehingga tidak diketahui hubungan antara satu faktor dengan faktor lainnya.

Saran untuk penelitian selanjutnya adalah dilakukan observasi luaran pasien dalam jangka waktu tertentu dan faktor-faktor yang memengaruhinya. Luaran pasien yang dapat diteliti terdiri dari survival (hidup atau meninggal) dan functional recovery (pemulihan baik, cacat sedang, cacat berat, vegetatif persisten). Penelitian lebih lanjut diperlukan untuk mengetahui faktor-faktor yang memengaruhi luaran pasien perdarahan intraserebral traumatik secara lebih menyeluruh dengan memperhatikan hubungan antar faktor.

\section{Simpulan}

Mayoritas pasien dengan perdarahan intraserebral traumatik berjenis kelamin laki-laki, kelompok usia 15- 64 tahun dengan mekanisme cedera berupa kecelakaan yang melibatkan kendaraan bermotor. Faktor-faktor yang memengaruhi luaran pasien perdarahan intraserebral traumatik adalah usia, skor GCS, dan ada tidaknya perdarahan otak lain. Hasil analisis data 60 pasien perdarahan intraserebral traumatik menunjukkan pasien dengan usia tua, skor GCS yang rendah saat masuk rumah sakit, serta adanya perdarahan otak lain memiliki luaran yang lebih buruk.

\section{Daftar Pustaka}

1. McCance KL, Huether SE. Pathophysiology: the biologic basis for disease in adults and children. 7th Edition. St.Louis: Missouri; 2014.

2. World Health Organization. Neurological disorders: a public health approach. Neurol Disord public Heal challenges. 2006;41-176.

3. Judiza Rarji Zahir BE. Helm : Manual keselamatan jalan untuk pengambil keputusan dan praktisi. 2014;12.

4. Mathers CD, Stein C, Fat DM. Global Burden of Disease 2000: Version 2 methods and results. Colin. 2002;(50).

5. Ji-Yao J, Guo-Yi G, Wei-Ping L, Ming-Kun Y, Cheng Z. Early indicators of prognosis in 846 cases of severe traumatic brain injury. J Neurotrauma. 2002;19(7):869-74.

6. Kementrian Kesehatan RI. Riset Kesehatan Dasar RISKESDAS 2018. Riset Kesehatan Dasar. 2018;

7. Aguilar MI, Brott TG. Update in Intracerebral Hemorrhage. The Neurohospitalist. 2011;1(3):148-59.

8. Perel P, Roberts I, Bouamra O. Intracranial bleeding in patients with traumatic brain injury: A prognostic study. 


\section{Research Article}

BMC Emerg Med. 2009;9(1):15.

9. Herou E, Romner B, Tomasevic G. Acute Traumatic Brain Injury: Mortality in the Elderly. World Neurosurg Elsevier Inc; 2015;83(6):996-1001.

10. Maas AI, Stocchetti N, Bullock R. Moderate and severe traumatic brain injury in adults. Lancet Neurol. 2008;7(8):728-41.

11. Baum J, Entezami P, Shah K, Medhkour A. Predictors of Outcome in Traumatic Brain Injury. World Neurosurg [Internet]. [Cited: 2017 Oct 22]. Elsevier Ltd; 2016; Available from: http://dx.doi.org/10.1016/j.wneu.2015.12.012

12. Gorelick PB, Testai F, Hankey G, Wardlaw JM. Hankey's Clinical Neurology, Second Edition. Taylor \& Francis; 2014.

13. Grigorakos L, Alexopoulou A, Tzortzopoulou K. Predictors of Outcome in Patients with Severe Traumatic Brain Injury. J Neurosci Clin Res. 2017;1-4. Available from: https://www.scitechnol.com/peer-review/predictors-ofoutcome-in-patients-with-severe-traumatic-brain-injury-4oea.php?article_id=5494

14. El-Menyar A, Consunji R, Abdelrahman H. Predictors and Time-Based Hospital Mortality in Patients with Isolated and Polytrauma Brain Injuries. World J Surg [Cited: 2017 Oct 22]. Springer International Publishing; 2017; Available from: http://link.springer.com/10.1007/s00268-017-4310-2

15. Hukkelhoven C, Steyerberg EW, Maas AI, Murray GD. Patient Age and Outcome following Severe TBI: Analysis of 5600 patients. J Neurosurg. 2003;99:666-73.

16. Roos KL. Emergency Neurology. Springer New York; 2012.

17. Simon RP, Aminoff MJ, Greenberg D. Clinical Neurology 9/E. McGraw-Hill Education; 2015.

18. Jennett B, Bond M. Outcome. Lancet. 1975;1(7905):480-4.

19. Staton C, Vissoci J, Gong E. Road Traffic Injury Prevention Initiatives: A Systematic Review and Metasummary of Effectiveness in Low and Middle Income Countries. PLoS One. 2016;11(1):1-15. 